\title{
Acetyl-CoA-dependent pyruvate carboxylase from the photosynthetic bacterium Rhodobacter capsulatus: rapid and efficient purification using dye-ligand affinity chromatography
}

\author{
Hemalata V. Modak† and David J. Kelly
}

Author for correspondence: David J. Kelly. Tel: +44 114282 4414. Fax: +44 1142728697.

e-mail: d.kelly@sheffield.ac.uk

Department of Molecular Biology and Biotechnology, University of Sheffield, PO Box 594, Firth Court, Western Bank, Sheffield S10 9UH, UK
Pyruvate carboxylase (PC) was purified to homogeneity from an overexpressing strain of the purple photosynthetic bacterium Rhodobacter capsulatus using a rapid dye-ligand affinity chromatography procedure, in which dye-bound enzyme was specifically eluted with a low concentration of acetyl-CoA, an allosteric activator of the enzyme. The enzyme purified by this method was obtained in $\mathbf{7 5} \%$ yield with a specific activity of $\mathbf{4 0} \mathrm{U}$ (mg protein) ${ }^{-1}$. In contrast, affinity chromatography on a monomeric avidin column, commonly used in the purification of biotin-containing carboxylases, resulted in a yield of $<40 \%$, with a specific activity of $10 \mathrm{U}\left(\mathrm{mg}\right.$ protein) ${ }^{-1}$. The enzyme purified by the dye-linked procedure had a subunit molecular mass of $140000 \mathrm{Da}$ and was absolutely dependent on acetyl-CoA for activity. AcetylCoA was also effective in protecting the enzyme from thermal denaturation. The enzyme was inhibited by 2-oxoglutarate and, to a lesser extent, L-aspartate, with sigmoidal kinetics with respect to acetyl-CoA concentration. The amino acid composition, pH optimum and kinetic constants for pyruvate, ATP and bicarbonate were determined. An N-terminal sequence of 26 residues was obtained, which was homologous to the $\mathrm{N}$-terminal regions of several eukaryotic PCs, propionyl-CoA carboxylases and acetyl-CoA carboxylase.

Keywords: pyruvate carboxylase, Rbodobacter capsulatus, dye-ligand chromatography, acetyl-CoA, N-terminal sequence

\section{INTRODUCTION}

Pyruvate carboxylase (PC; EC 6.4.1.1) is an important and widely distributed biotin-containing enzyme found in many mammalian, fungal and plant tissues, as well as in some groups of bacteria (Keech \& Wallace, 1985). It catalyses a two-step reaction, involving (i) the ATPdriven carboxylation of a covalently attached biotin moiety and (ii), the transfer of the bound carboxyl group to pyruvate, forming oxaloacetate. In bacteria, PC has an anaplerotic role in the provision of oxaloacetate for both

†Present address: Department of Microbiology, University of Ohio, Columbus OH 43210-1292, USA.

Abbreviations: HRP, horseradish peroxidase; ICM, intra-cytoplasmic membrane; $\mathrm{PC}$, pyruvate carboxylase. biosynthetic purposes and as a carrier for acetyl units into the citric acid cycle. Mutants deficient in PC were first isolated from the photosynthetic bacterium Rhodobacter sphaeroides (Payne \& Morris, 1969) and more recently from R. capsulatus (Willison 1988). Such mutants are highly pleiotropic and are unable to grow either autotrophically or on any carbon sources metabolized through pyruvate. Pyruvate carboxylase is clearly a key enzyme which contributes to the well-known metabolic versatility of Rhodobacter and its properties are therefore of some interest.

PCs isolated from diverse sources show varying degrees of dependence on acetyl-CoA as an allosteric activator. For example, PC from Pseudomonas citronellolis (Suebert \& Weicker, 1969; Taylor et al., 1972), Aspergillus niger (Feir \& Suzuki, 1969) and Azotobacter vinelandii (Scrutton \& Taylor, 1974) do not require acetyl-CoA for activity, 
while most of the vertebrate enzymes have negligible activity in its absence. The enzyme from yeast is active in the absence of acetyl-CoA but its addition causes a threeto fourfold stimulation of activity (Ruiz-Amil et al., 1965). In general terms, the acetyl-CoA-dependent enzymes are homotetramers with a subunit molecular mass of $110-140 \mathrm{kDa}$, while the $P$. citronellolis and $A$. vinelandii enzymes are heterodimers or tetramers with subunit molecular masses of 65 and $54 \mathrm{kDa}$ (Scrutton \& Young, 1972; Taylor et al., 1972; Barden et al., 1975). PC is one of a number of related enzymes which use biotin as a mobile prosthetic group to move a bound carboxyl group between two subsites within the protein. The reaction mechanism has recently been studied in some detail by conventional steady-state methods, labelling and isotope exchange techniques (Phillips et al., 1992). The available data point toward the initial formation of a carboxyphospho-enzyme complex which precedes conversion to the more stable carboxybiotin-enzyme, and it is now clear that acetyl-CoA acts by shifting the equilibrium towards the latter.

In addition to its stimulatory effects on enzyme activity, acetyl-CoA also has a stabilizing effect on the enzyme. Ashman et al. (1972) showed that the loss of activity associated with dilution of all vertebrate PCs below 3-4 $\mathrm{U} \mathrm{ml}^{-1}$ (due to dissociation of the tetrameric enzyme into monomers) does not occur in the presence of acetylCoA. Similarly, dissociation of the enzyme into monomers at low temperature is prevented in the presence of acetylCoA (Scrutton \& Utter, 1965) although its addition to previously cold- or dilution-inactivated enzyme does not restore activity. By mediating subunit interactions, acetylCoA thus appears to maintain the enzyme in an active conformation.

The purification of PC from mammalian or bacterial sources has traditionally been based on the use of avidinaffinity chromatography with specific elution by excess biotin. There are, however, a number of disadvantages associated with this method, particularly the low capacity and high cost of avidin columns (making scale-up difficult), and the need to remove other biotin-containing proteins prior to adsorption, to avoid co-elution with PC. In this paper, an alternative purification procedure for a major class of PC is described, which makes use of the interaction of the enzyme with acetyl-CoA. The method has been used to characterize the PC from $R$. capsulatus and to obtain the first $\mathrm{N}$-terminal sequence data from a bacterial PC.

\section{METHODS}

Strains, media and growth conditions. Rhodobacter capsulatus strain PAS100 (Taylor et al., 1983) was the parent strain used in these studies. It was routinely grown chemoheterotrophically at $30^{\circ} \mathrm{C}$ in RCV minimal medium (Weaver et al., 1975; Hillmer \& Gest, 1977) containing $\mathrm{D}, \mathrm{L}$-lactate $(0.4 \%$, w/v) as carbon source. Mutants derived from PAS100 lacking PC were routinely grown in the same medium but with $0.4 \%(\mathrm{w} / \mathrm{v}) \mathrm{D}, \mathrm{L}-$ malate as carbon source. Other sole carbon sources used in growth tests were also $0.4 \%(w / v)$. For photoheterotrophic growth, cultures were incubated in completely filled bottles at a distance of $30 \mathrm{~cm}$ from a $60 \mathrm{~W}$ tungsten bulb. Photoautotrophic growth tests were conducted in an anaerobic cabinet (Don Whitley, Shipley, UK) under an atmosphere of $\mathrm{N}_{2} / \mathrm{CO}_{2} / \mathrm{H}_{2}$ ( $85: 10: 5$, by vol.) on RCV plates containing no added organic carbon source. Illumination was provided by a bank of tungsten striplights above the cabinet. Escherichia coli strains were grown aerobically in LB medium (Sambrook et al., 1989). Antibiotics were used at the following concentrations; kanamycin, $25 \mu \mathrm{g} \mathrm{ml}^{-1}$; tetracycline, $10 \mu \mathrm{g} \mathrm{ml}^{-1}$ (E. coli) or $1 \mu \mathrm{g} \mathrm{ml}^{-1}$ (R. capsulatus).

Isolation of mutants. Transposon mutagenesis with $\operatorname{Tn} 5$ was used to isolate mutants lacking PC activity. E. coli S171(pSUP2021) (Simon et al., 1983) was mated with R. capsulatus PAS100 on nitrocellulose filters exactly as described by Hamblin et al. (1990). Transconjugants appearing on RCV-malatekanamycin plates were tested for growth on RCV-lactatekanamycin plates and those unable to grow were retained and assayed for PC activity.

DNA isolation and manipulation. Small-scale isolation of cosmids and plasmids from both E. coli and R. capsulatus was done using the rapid boiling method (Sambrook et al., 1989). Large-scale plasmid DNA preparations were obtained after lysozyme/SDS treatment followed by polyethylene glycol 8000 (PEG) precipitation and caesium chloride isopycnic centrifugation. Genomic DNA was prepared by lysosyme/SDS treatment, chloroform extraction and caesium chloride gradient centrifugation. Restriction endonuclease analysis, agarose gel electrophoresis, Southern blotting and ligation were performed according to standard procedures (Sambrook et al., 1989). Bacterial transformations were performed by the method of Hanahan (1985).

DNA cloning and complementation of mutants. The gene bank described by Colbeau et al. (1986) was used to clone DNA complementing the $\operatorname{Tn} 5$ mutants. It consists of eight pools of 200 randomly picked colonies of E. coli HB101, each containing a size-fractioned partial EcoRI fragment of chromosomal DNA from $R$. capsulatus strain B10, cloned in the broad host-range cosmid vector pLAFR 1 . The mean insert size is approximately $20 \mathrm{~kb}$. Each pool was conjugated with R. capsulatus HVM13 in a separate triparental filter mating with pRK2013 as helper plasmid, as described by Hamblin et al. (1990). Transconjugants were selected aerobically in the dark on RCV-pyruvate plates containing kanamycin and tetracycline. The efficiency of transfer was determined on RCV-D,L-malate plates containing the same antibiotics. A $10 \mathrm{~kb} \mathrm{Bam} \mathrm{HI} \mathrm{fragment} \mathrm{common} \mathrm{to} \mathrm{two} \mathrm{comple-}$ menting cosmids (designated pPYC100 and PPYC200) was cloned from pPYC100 into the broad-host range plasmid pRK415 (Keen et al., 1988) and designated pPYC101.

Overexpression of PC activity. E. coli $\mathrm{S} 17-1$ (pPYC101) was conjugated with $R$. capsulatus PAS100, and the transconjugants were selected on RCV-pyruvate plates containing tetracycline. One colony was purified and grown aerobically in the dark in $\mathrm{RCV}$-pyruvate medium. PC activities in cell-free extracts were determined as described below. E. coli S17-1(pPYC101) was grown in M9 minimal medium (Sambrook et al., 1989) containing tetracycline and with pyruvate as the carbon source. Cell-free extracts were prepared by sonication and assayed for $\mathrm{PC}$ activity as described below.

Enzyme assays. Cell-free extracts were routinely prepared from $250 \mathrm{ml}$ cultures grown aerobically in the dark on RCV-malate medium (with pyruvate or acetate added at $10 \mathrm{mM}$ final concentration for induction of the enzyme activities where necessary). Cells were harvested by centrifugation, washed with ice-cold $50 \mathrm{mM}$ Tris $/ \mathrm{HCl}, \mathrm{pH} 8.0$, then resuspended in $1 \mathrm{ml}$ of the same buffer followed by sonication (MSE Soniprep 150, 
$6 \times 20 \mathrm{~s}$ bursts, $8 \mu \mathrm{m}$ amplitide). Debris was removed by centrifugation at $13000 \mathrm{~g}$ for $10 \mathrm{~min}$ at $4{ }^{\circ} \mathrm{C}$. Protein concentration was determined using the Lowry method.

PC activity was measured by three methods. (a) The first assay was that of Payne \& Morris (1969), where the oxaloacetate produced by $\mathrm{PC}$ is converted to citrate by added citrate synthase in the presence of acetyl-CoA and 5,5'-dithio-bis(2-nitrobenzoate) (DTNB). The rate of increase in absorbance at $412 \mathrm{~nm}$ due to the CoA-dependent appearance of the thionitrobenzoate anion $\left(\varepsilon=13.6 \mathrm{mM}^{-1} \mathrm{~cm}^{-1}\right)$ was measured first after the addition of pyruvate to the assay mixture and then after the addition of ATP. The difference between the two rates was taken as the PC activity. This assay was used in crude extracts and during purification. The complete assay mixture contained, in a final volume of $1 \mathrm{ml}$ : Tris $/ \mathrm{HCl}$ buffer, $\mathrm{pH} 8.0,100 \mathrm{mM}$; magnesium chloride, $5 \mathrm{mM}$; sodium bicarbonate, $50 \mathrm{mM}$; ATP, $5 \mathrm{mM}$; sodium pyruvate, $5 \mathrm{mM}$; acetyl-CoA, $0.1 \mathrm{mM}$; DTNB, $0.25 \mathrm{mM}$; citrate synthase (Sigma) $2 \mathrm{U}$. (b) In the second assay, oxaloacetate production was linked to malate dehydrogenase. This was used for kinetic studies on the pure enzyme and for studying acetyl-CoA dependence. The same assay mixture as in (a) was used, with the omission of citrate synthase and DTNB, and with the addition of $2 \mathrm{U}$ of malate dehydrogenase (Sigma) and sufficient NADH to give an initial absorbance at $340 \mathrm{~nm}$ of $0 \cdot 8-0 \cdot 9$. The assay was started by the addition of pyruvate. (c) The third assay measured ${ }^{14} \mathrm{CO}_{2}$ fixation by the purified enzyme. The assay mixture contained in a total volume of $0.5 \mathrm{ml}$ : Tris $/ \mathrm{HCl}$ buffer, $\mathrm{pH} 8.0,100 \mathrm{mM}$; sodium pyruvate or other organic acid (where tested), $50 \mathrm{mM}$; ATP, $2 \mathrm{mM} ; \mathrm{MgCl}_{2}, 4 \mathrm{mM}$; acetyl-CoA $0.1 \mathrm{mM} ; \mathrm{NaH}^{14} \mathrm{CO}_{3}$ $\left[1 \cdot 85-2 \cdot 2 \mathrm{GBq} \mathrm{mmol}^{-1}\right.$ ], $25 \mathrm{mM}$; pure PC, $0 \cdot 5 \mu \mathrm{g}$. After $30 \mathrm{~min}$ the reaction was stopped by the addition of $0.2 \mathrm{ml} 12 \mathrm{M}$ formic acid, and the mixture heated for $2 \mathrm{~h}$ at $80^{\circ} \mathrm{C}$. Aliquots were then counted by scintillation spectrometry. Phosphoenolpyruvate carboxykinase (EC 4.1.1.49) was measured as described by Schobert \& Bowien (1984), pyruvate kinase (EC 2.7.1.40) as described by Hess \& Wieker (1974), pyruvate dehydrogenase complex (EC 1.2.4.1) as described by Guest \& Creaghan (1973) and lactate dehydrogenase (EC 1.1.1.27) in a mixture $(1 \mathrm{ml})$ containing: Tris/ $\mathrm{HCl}$ buffer, $\mathrm{pH} 8 \cdot 0,100 \mathrm{mM}$; NADH, $0.2 \mathrm{mM}$; sodium pyruvate, $5 \mathrm{mM}$; rotenone, $0.1 \mathrm{mM}$. D-Malic enzyme (malate dehydrogenase; EC 1.1.1.38) was assayed in a mixture containing Tris/ $\mathrm{HCl}$ buffer, $\mathrm{pH} 7 \cdot 0,100 \mathrm{mM}$; NAD, $2.5 \mathrm{mM}$; manganese chloride, $2 \mathrm{mM}$; potassium chloride, $5 \mathrm{mM}$; $\mathrm{D}(+)$-malate, $7.5 \mathrm{mM}$; rotenone, $0.1 \mathrm{mM}$. Isocitrate lyase (EC 4.1.3.1) and malate synthase (EC 4.1.3.2) were assayed as described by Dixon \& Kornberg (1959), acetate kinase (EC 2.7.2.1) as described by Fox \& Roseman (1986) and phosphotransacetylase (EC 2.3.1.8) as described by Wooford et al. (1986). All assays using NAD or NADH were monitored at $340 \mathrm{~nm}\left(\varepsilon=6.22 \mathrm{mM}^{-1} \mathrm{~cm}^{-1}\right)$.

Detection of biotinylated proteins by Western blotting. Cellfree extracts were prepared as described above from wild-type or mutant cells grown on RCV-malate medium. An SDSPAGE gel $(10 \%, w / v$, acrylamide) was loaded with equal amounts of denatured extract protein $(300 \mu \mathrm{g})$ and with biotinylated molecular mass standards (BioRad; gel loadings as recommended by the manufacturer). After electrophoresis at $30 \mathrm{~mA}$ for $5 \mathrm{~h}$, the gel was blotted onto nitrocellulose in a BioRad Transblot cell at $250 \mathrm{~mA}$ for $16 \mathrm{~h}$. Biotinylated polypeptides were detected using an avidin-horseradish peroxidase (HRP) conjugate (BioRad) according to the following procedure. The nitrocellulose membrane was immersed in blocking solution $(3 \% \mathrm{w} / \mathrm{v}$ bovine serum albumin in Tris-buffered saline (TBS; $20 \mathrm{mM}$ Tris $/ \mathrm{HCl}, \mathrm{pH} 7 \cdot 5$, containing $500 \mathrm{mM} \mathrm{NaCl}$ ) for 30 min. After washing twice (5 min each wash) with $0.05 \%$ (v/v) Tween 20 in TBS (TTBS), the membrane was transferred to $100 \mathrm{ml}$ TTBS containing $1 \%(\mathrm{w} / \mathrm{v})$ bovine serum albumin and a 1:3000 dilution of the avidin-HRP conjugate. After a $1 \mathrm{~h}$ incubation with shaking, the solution was removed, and the membrane washed twice in TTBS and then twice in TBS $(5 \mathrm{~min}$ each wash). Finally, the membrane was placed in the colour development solution (100 ml TBS containing $25 \mathrm{mg} \mathrm{3,3'}$ diaminobenzidine- $\mathrm{HCl}, 30 \mathrm{mg}$ nickel chloride and $5 \mu \mathrm{l} 30 \%$, $\mathrm{v} / \mathrm{v}$, hydrogen peroxide solution) for up to $1 \mathrm{~h}$.

\section{Purification of PC by avidin-affinity chromatography}

Step 1. Crude extract and removal of membrane proteins. Cells of $R$. capsulatus PAS100(pPYC101) grown in RCV-lactate medium were resuspended in Buffer $\mathrm{A}$ (Tris/ $\mathrm{HCl}$ buffer, $\mathrm{pH} 8.0$, containing $10 \mathrm{mM}$ magnesium chloride, $1 \mathrm{mM}$ EDTA, $0 \cdot 1 \mathrm{mM}$ PMSF and $0 \cdot 1 \mathrm{mM}$ DTT and disrupted by passage through a French Press. Cell debris was removed by centrifugation at $12000 \mathrm{~g}$ for $20 \mathrm{~min}$ at $4{ }^{\circ} \mathrm{C}$. Intracytoplasmic membranes were removed from the supernatant by a further centrifugation at $100000 \mathrm{~g}$ for $2 \mathrm{~h}$ at $4^{\circ} \mathrm{C}$, and the supernatant retained.

Step 2. Ammonium sulphate precipitation. Solid ammonium sulphate was added to the membrane-free supernatant to $40 \%$ (w/v) saturation, stirred slowly at $4{ }^{\circ} \mathrm{C}$ for $20 \mathrm{~min}$ and then centrifuged $\left(20000 \mathrm{~g}, 4{ }^{\circ} \mathrm{C}, 20 \mathrm{~min}\right)$. The supernatant was brought to $50 \%(\mathrm{w} / \mathrm{v})$ ammonium sulphate saturation and centrifuged $\left(20000 \mathrm{~g}, 4{ }^{\circ} \mathrm{C}, 20 \mathrm{~min}\right)$. The pellet was resuspended in Buffer B (Buffer A containing 20\%, v/v, glycerol) and dialysed at $4{ }^{\circ} \mathrm{C}$ against several changes of Buffer $\mathrm{B}$ over a period of $2-3 \mathrm{~h}$.

Step 3. Ultrafiltration. The dialysed fraction from step 2 was concentrated and further purified by ultrafiltration in a Filtron stirred cell (Flowgen) with a membrane with a $100000 \mathrm{Da}$ cutoff.

Step 4. Anion exchange chromatography. A DEAE-sepharose CL$6 \mathrm{~B}$ column $(10 \times 1 \mathrm{~cm})$ was equilibrated with Buffer $B$ and the concentrate from step 3 (about 1-2 $\mathrm{mg}$ protein $\mathrm{ml}^{-1}$ ) loaded at a flow rate of $0.5 \mathrm{ml} \mathrm{min}^{-1}$. PC activity was eluted by an increasing salt gradient $(0-250 \mathrm{mM} \mathrm{KCl})$. Active fractions were pooled and dialysed against several changes of Buffer $B$.

Step 5. Avidin-affinity chromatography. A monomeric avidin column (Sigma) was prepared for use by first blocking the nonexchangeable biotin-binding sites with $0.2 \mathrm{mM}$ biotin, followed by washing with $0 \cdot 1 \mathrm{M}$ glycine in $0.2 \mathrm{M} \mathrm{KCl}$ (adjusted to $\mathrm{pH} 1.5$ with $\mathrm{HCl}$ ) to remove biotin from the exchangeable sites. The dialysed active fractions from step 4 were loaded onto the Buffer $B$ equilibrated column at a slow flow-rate $\left(0 \cdot 3 \mathrm{ml} \mathrm{h}^{-1}\right)$ and pure PC eluted with biotin $\left(2 \mathrm{mg} \mathrm{ml}^{-1}\right)$.

\section{Purification of PC by dye-ligand affinity chromatography}

Steps 1 and 2. The production of a membrane-free cell extract and ammonium sulphate precipitation were performed as described above.

Step 3. Blue MX-3B chromatography. A column $(10 \times 1 \mathrm{~cm})$ of the triazine dye Blue MX-3B (ICI dyestuffs division) linked to sepharose CL-6B was equilibrated with Buffer B. The dialysed fraction from step 2 was loaded on at a flow rate of $1 \mathrm{ml} \mathrm{min}^{-1}$ and the column washed with Buffer B until the absorbance of the effluent at $280 \mathrm{~nm}$ was negligible. The column was then washed with $100 \mathrm{ml} \mathrm{Buffer} \mathrm{C} \mathrm{(Buffer} \mathrm{B} \mathrm{containing} 50 \mathrm{mM} \mathrm{KCl}$ ) to remove non-specifically bound proteins and subsequently with $30 \mathrm{ml}$ of Buffer B. PC was specifically eluted with $10 \mathrm{ml}$ Buffer D (Buffer B containing $50 \mu \mathrm{M}$ acetyl-CoA). Active fractions were pooled and stored at $-20{ }^{\circ} \mathrm{C}$ after addition of glycerol to a final concentration of $50 \%(\mathrm{w} / \mathrm{v})$. 
Amino acid composition and $\mathbf{N}$-terminal sequence. Enzyme samples dialysed against distilled water were evaporated to dryness and hydrolysed in $6 \mathrm{M} \mathrm{HCl}$ containing $0.1 \%(\mathrm{v} / \mathrm{v})$ phenol for 24 and $48 \mathrm{~h}$. Amino acid composition was determined on a Waters Pico-Tag system using 2-aminohexanoic acid (norleucine) as an internal standard. Compositional relatedness between PCs was estimated using the procedure of Marchelonis \& Weltman (1971). N-terminal sequencing was performed using the automated Edman degradation procedure.

\section{RESULTS}

\section{Identification and overexpression of the R. capsulatus PC}

Mutants specifically lacking PC activity were isolated by transposon mutagenesis with $\operatorname{Tn} 5$, as described in Methods. Five mutants unable to grow on pyruvate, acetate, lactate, D-malate or autotrophically but showing normal growth on L-malate, were isolated. All five mutants lacked PC activity, but contained wild-type levels of pyruvate kinase, phosphoenolpyruvate carboxykinase,

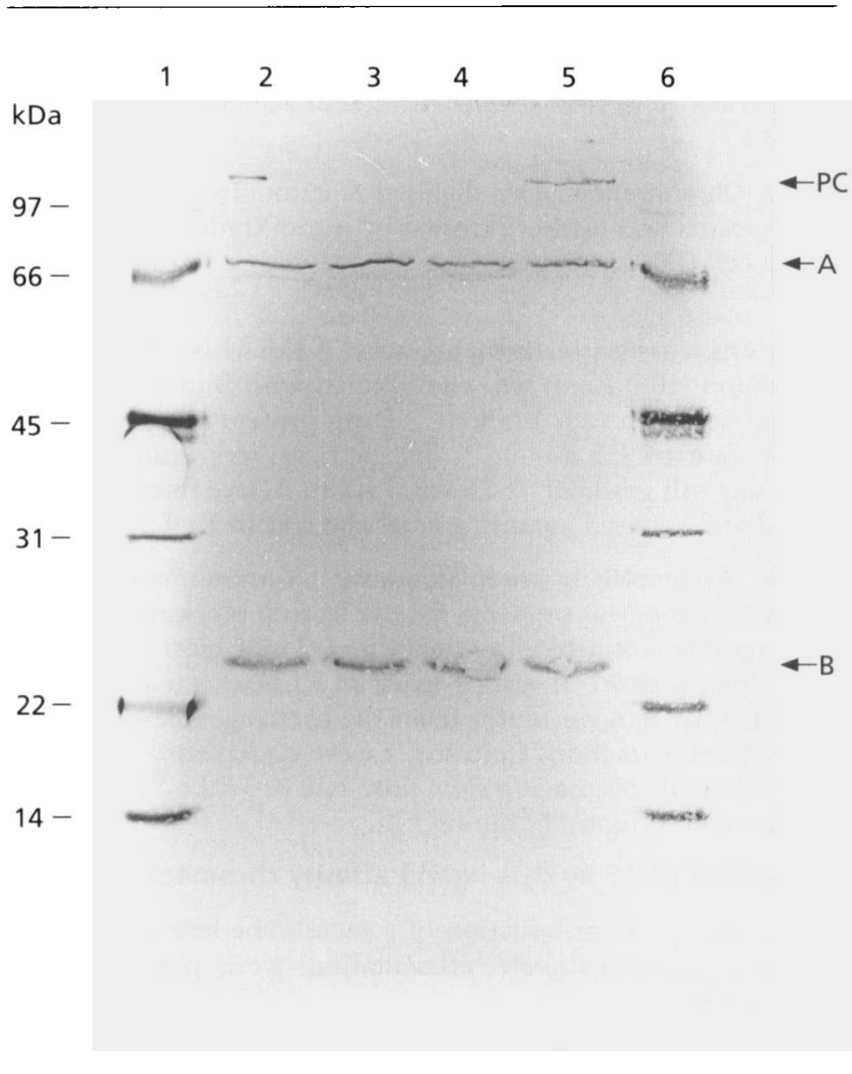

Fig. 1. Detection of biotinylated polypeptides in wild-type and mutant cell-free extracts. Cell-free extracts ( $300 \mu \mathrm{g}$ protein) were denatured in SDS-sample buffer at $80^{\circ} \mathrm{C}$ for $5 \mathrm{~min}$, then loaded onto a $10 \%$ polyacrylamide gel. After electrophoresis and Western blotting, biotinylated proteins were detected as described in Methods. Lanes: 1 and 6, biotinylated molecular mass markers (phosphorylase $\mathrm{B}, 97 \mathrm{kDa}$; bovine serum albumin, $66 \mathrm{kDa}$; ovalbumin, $45 \mathrm{kDa}$; carbonic anhydrase, $31 \mathrm{kDa}$; soybean trypsin inhibitor, $22 \mathrm{kDa}$; lysosyme, $14 \mathrm{kDa}$ ); 2 and 5 , PAS100; 3, HVM13; 4, HVM14. Proteins A and B are unidentified biotinylated proteins (see text).

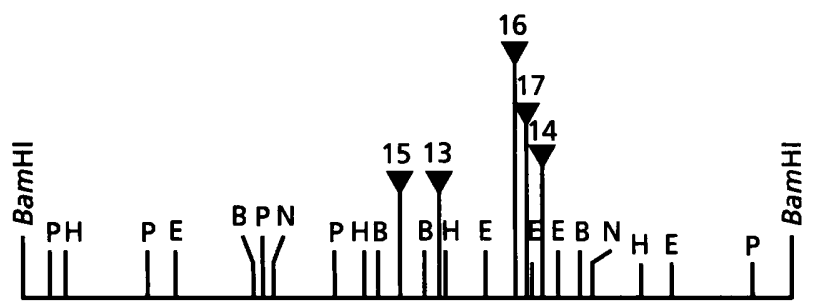

$1 \mathrm{~kb}$

Fig. 2. Restriction map of the $10 \mathrm{~kb}$ BamHI insert in pPYC101 and relative positions of the Tn5 insertions in the mutant genomic DNA. The numbers 13-17 refer to the positions of Tn5 in mutants HVM13-17, as determined by Southern blotting of chromosomal BamHI, HindIII and Pstl restriction digests with a Tn5 probe and comparison with the restriction map. B, BgIII; E, EcoRI; H, HindIII; N, Nrul; P, Pstl.

lactate dehydrogenase, pyruvate dehydrogenase, D-malic enzyme, acetate kinase, phosphotransacetylase, isocitrate lyase and malate synthase (data not shown). A Western blot of cell-free extracts of two of the mutants (HVM13 and HVM14), along with PAS100, was obtained and incubated with an avidin-HRP conjugate. The PAS100 cell-free extract contained at least three biotin containing polypeptides (Fig. 1), of approximate molecular masses 140,70 and $23 \mathrm{kDa}$. HVM13 and HVM14 were found to be deficient specifically in the $140 \mathrm{kDa}$ protein, thus confirming its identity as PC. The identity of the two other biotinylated proteins is unknown, but the $23 \mathrm{kDa}$ protein is similar in size to the biotin-carboxylase subunit of acetyl-CoA carboxylase in other bacteria (Buckley et al., 1969).

One of the mutants (HVM13) was complemented in trans by conjugation with a wild-type cosmid gene bank. Ten colonies able to grow on pyruvate as sole carbon source were purified and found to contain two types of cosmid after restriction analysis (data not shown), which were designated pPYC100 and pPYC200. Both cosmids contained a common $10 \mathrm{~kb}$ Bam HI fragment which was subcloned from pPYC100 into the broad host-range vector $\mathrm{pRK} 415$ to give $\mathrm{pPYC101}$. Transfer of pPYC101 to HVM13 by conjugation also resulted in complementation to growth on pyruvate, indicating that the structural gene encoding PC or a regulatory gene required for its expression (or both) had been cloned. In a typical experiment, transfer of pPYC101 to the R. capsulatus wildtype strain PAS100 resulted in an increase in PC-specific activity in cell-free extracts from 35 to $360 \mathrm{nmol} \mathrm{min}{ }^{-1}$ (mg protein) ${ }^{-1}$. Transfer of only the vector (pRK415) to R. capsulatus resulted in no significant increase in activity. No expression $\left.\left[<1 \mathrm{nmol} \mathrm{m^{-1 }} \text { (mg protein }\right)^{-1}\right]$ was detected in E. coli S17-1 with or without these plasmids. Fig. 2 shows a restriction map of the insert in pPYC101, together with the positions of the $\operatorname{Tn} 5$ insertions in the corresponding chromosomal DNA of the mutants, as determined by Southern blotting. All of the insertions mapped within the same $1.9 \mathrm{~kb}$ region. 
Table 1. Purification of $R$. capsulatus PC by avidin-affinity chromatography

\begin{tabular}{|lccccc|}
\hline Step & $\begin{array}{c}\text { Protein } \\
\text { (mg) }\end{array}$ & $\begin{array}{c}\text { Activity } \\
\text { (U) }\end{array}$ & $\begin{array}{c}\text { Specific activity } \\
{[\mathbf{U} \text { (mg protein) }}\end{array}$ & $\begin{array}{c}\text { Purification } \\
\text { (-fold) }\end{array}$ & $\begin{array}{c}\text { Yield } \\
\text { (\%) }\end{array}$ \\
\hline ICM-free crude extract & 400 & 160 & $0 \cdot 4$ & $1 \cdot 0$ & 100 \\
$40-50 \%\left(\mathrm{NH}_{4}\right)_{2} \mathrm{SO}_{4}$ & 160 & 150 & $1 \cdot 0$ & $2 \cdot 5$ & 95 \\
Ultrafiltration & 68 & 140 & $2 \cdot 0$ & $5 \cdot 0$ & 87 \\
DEAE-sepharose & 12 & 60 & $5 \cdot 0$ & $12 \cdot 5$ & 40 \\
Avidin-sepharose & $0 \cdot 01$ & $0 \cdot 1$ & $10 \cdot 0$ & $25 \cdot 0$ & $-*$ \\
\hline
\end{tabular}

* The yield could not be calculated at this step because of the low capacity of the avidin-sepharose column; not all the PC was able to bind.

\section{Avidin-affinity purification of PC}

The strain used for all of the purification studies was $R$. capsulatus PAS100(pPYC101). We first devised a purification procedure based on the well known monomeric avidin-affinity chromatography method (Henrikson $e t$ al., 1979), which has become the standard technique to purify PCs from diverse sources. A cell-free extract was ultracentrifuged to remove intra-cytoplasmic membranes (ICMs) and the supernatant subjected to ammonium sulphate fractionation and ultrafiltration, followed by dialysis and then ion-exchange chromatography on DEAE-sepharose. PC activity eluted at $80 \mathrm{mM} \mathrm{KCl}$ from the DEAE column. The active fractions were pooled, dialysed, concentrated and applied to the avidin column. Enzyme activity could be eluted with biotin. SDS-PAGE of the eluant from the avidin column revealed the presence of a single polypeptide of approximate molecular mass $140 \mathrm{kDa}$. A summary of the purification is given in Table 1. This procedure produced a low yield of enzyme with a relatively low specific activity.

\section{Development of a dye-ligand based affinity purification procedure}

In view of the inefficiency of the conventional avidinaffinity method for this enzyme, an alternative technique based on the use of triazine dye-affinity chromatography was developed. Initially, a number of such dyes linked to sepharose $4 \mathrm{~B}$ were screened for their ability to bind a low amount of total protein but significant amounts of PC activity from ammonium sulphate fractionated extracts which had been dialysed to remove excess salt. Of those columns tested, Blue MX-37 and Blue MX-3B bound only about $10 \%(\mathrm{w} / \mathrm{w})$ of the total protein applied but virtually all of the PC activity. Blue H-ERD (Leyland \& Kelly, 1991) bound most of the PC activity applied, but also bound $70 \%(\mathrm{w} / \mathrm{w})$ of the total protein applied. A number of specific eluants were tested with these columns. It was found that little PC activity was eluted from the Blue H-ERD column under any conditions, even using $1 \mathrm{M} \mathrm{KCl}$. It was not used further. Pyruvate, bicarbonate, biotin and ATP did not result in elution of enzyme activity from any of the columns tested. However, it was found that $50 \mu \mathrm{M}$ acetyl-CoA in the elution buffer reproducibly released all of the PC bound to the Blue MX-

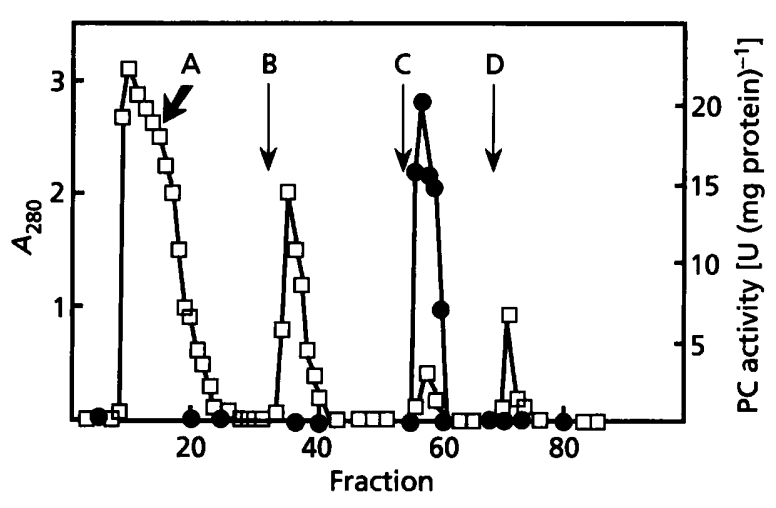

Fig. 3. Elution profile of PC activity from a Blue MX-3Bsepharose column. Total protein (measured as absorbance at $280 \mathrm{~nm}$; $\square$ ) and enzyme activity (O) was monitored. After loading the sample, excess unbound protein was eluted in the column effluent (A). Proteins binding non-specifically to the column were eluted with a $50 \mathrm{mM} \mathrm{KCl}$ wash (B), followed by specific elution of PC activity with $50 \mu \mathrm{M}$ acetyl-CoA (C). Addition of $1 \mathrm{M} \mathrm{KCl}$ (D) did not result in any further elution of PC activity, but released a small amount of residual protein.

37 and MX-3B columns (Fig. 3). Furthermore, it was observed that washing with $50 \mathrm{mM} \mathrm{KCl}$ prior to the addition of acetyl-CoA removed contaminating protein but did not result in the release of any PC activity (Fig. 3). A final wash with $1 \mathrm{M} \mathrm{KCl}$ removed remaining bound protein. Analysis by SDS-PAGE (Fig. 4) clearly showed the effectiveness and specificity of the acetyl-CoA elution; only a single polypeptide of approximate molecular mass $140 \mathrm{kDa}$ was visible after Coomassie blue staining.

A representative scaled-up purification using a Blue MX$3 \mathrm{~B}$ column is shown in Table 2 . In contrast to the avidinbased method, only $25 \%$ of the enzyme activity was lost during the dye-linked purification and the specific activity of the pure enzyme was much higher. The characterization described below was carried out using dye-purified enzyme.

\section{Kinetic properties of the dye-purified enzyme}

Affinity constants for bicarbonate, ATP and pyruvate are shown in Table 3 . With sodium pyruvate as the varied substrate, double reciprocal plots gave two linear inter- 


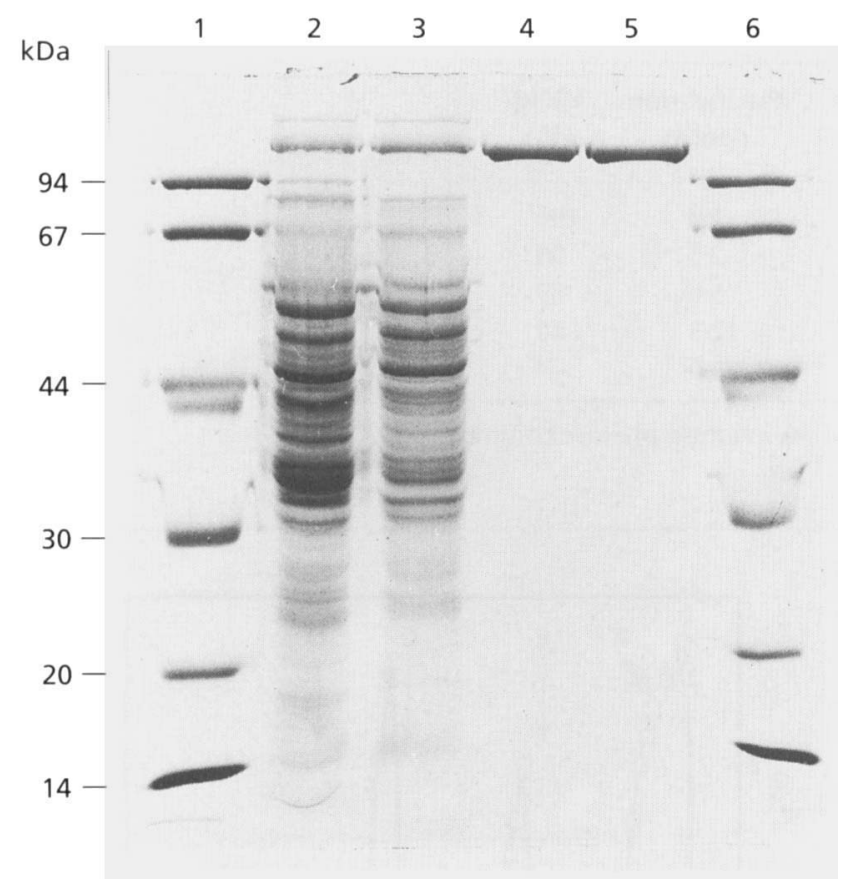

Fig. 4. SDS-PAGE analysis of PC purification by dye-ligand affinity chromatography. Lanes: 1 and 6, molecular mass standards (sizes indicated); 2, membrane-free cell extract; 3 , proteins fractionating between 40 and $50 \%$ ammonium sulphate saturation; 4, pooled active fractions from the Blue $\mathrm{MX}-3 \mathrm{~B}$ column; 5, pooled active fractions from a Blue MX-37 column for comparison. The gel was stained with Coomassie blue.

secting lines which could be extrapolated to two separate $K_{\mathrm{m}}$ values (data not shown). The purified PC showed an absolute requirement for acetyl-CoA. No activity was observed after dialysis to remove the acetyl-CoA used for elution from the dye-affinity column. However, a very low concentration of acetyl-CoA was found to be effective in activating the enzyme, and plots of rate against acetylCoA concentration were hyperbolic rather than sigmoidal (see Fig. 5b), with half-maximal activation $\left(K_{\mathrm{a}}\right)$ occurring at less than $0.5 \mu \mathrm{M}$ acetyl-CoA (Table 3). Coenzyme A could replace acetyl-CoA only poorly, with a $K_{\mathrm{a}}$ value three orders of magnitude higher (Table 3 ).

\section{Requirement for metal cations and effect of $\mathrm{pH}$ on activity}

PC activity was found to be completely dependent on the presence of divalent metal cations in the assay mixture.
Table 3. Summary of measured $K_{\mathrm{m}}$ and $K_{\mathrm{a}}$ values for the purified $R$. capsulatus PC

\begin{tabular}{|lll|}
\hline $\begin{array}{l}\text { Variable } \\
\text { component }\end{array}$ & $\begin{array}{c}\text { Kinetic } \\
\text { constant }\end{array}$ & $\begin{array}{c}\text { Value } \\
\text { (M) }\end{array}$ \\
\hline Pyruvate & $K_{\mathrm{m}} 1^{*}$ & $4.0 \times 10^{-4}$ \\
& $K_{\mathrm{m}} 2^{*}$ & $6.0 \times 10^{-5}$ \\
ATP & $K_{\mathrm{m}}$ & $2 \cdot 2 \times 10^{-4}$ \\
NaHCO & $K_{\mathrm{m}}$ & $8.3 \times 10^{-4}$ \\
Acetyl-CoA & $K_{\mathrm{a}}$ & $3.3 \times 10^{-7}$ \\
CoA & $K_{\mathrm{a}}$ & $6.6 \times 10^{-4}$ \\
\hline
\end{tabular}

* As with some other PCs, double reciprocal plots with pyruvate as the variable substrate showed two linear intersecting lines (see text for explanation). $K_{\mathrm{m}}$ values calculated from both intercepts are given.

Magnesium ions gave maximal specific activities [38-40 U $\left.(\mathrm{mg} \text { protein })^{-1}\right]$. Manganese ions were also effective $[20 \mathrm{U}$ (mg protein $)^{-1}$ at $\mathrm{pH} 7$ and $10 \mathrm{U}$ (mg protein) ${ }^{-1}$ at $\mathrm{pH} 8$; see below] but were inhibitory above a concentration of about $1.25 \mathrm{mM}$ (data not shown). Apart from a very low activity observed with copper II ions [about $3 \mathrm{U}$ (mg protein $)^{-1}$, no activity was demonstrable with $\mathrm{Co}^{2+}$, $\mathrm{Ni}^{2+}, \mathrm{Ca}^{2+}, \mathrm{Sr}^{2+}$ or $\mathrm{Zn}^{2+}$. The PC from Bacillus stearothermophilus is known to exhibit different $\mathrm{pH}$ optima in the presence of either magnesium or manganese as activating cations (Cazzulo et al., 1970). In the presence of magnesium at an equimolar concentration to ATP in the assay mixture, the $R$. capsulatus enzyme showed maximal activity at $\mathrm{pH} \mathrm{8.5,} \mathrm{which} \mathrm{was} \mathrm{shifted} \mathrm{slightly} \mathrm{to} \mathrm{pH} 8.0$ at a magnesium chloride concentration double that of ATP. However, in the presence of manganese chloride, the activity was highest at $\mathrm{pH} 7 \cdot 0$.

\section{Substrate-dependent $\mathrm{CO}_{2}$ fixation}

The requirements for the fixation of $\mathrm{CO}_{2}$ from $\mathrm{NaH}^{14} \mathrm{CO}_{3}$ into acid-stable products were determined for the pure enzyme. In the complete assay mixture (see Methods) significant pyruvate-dependent ${ }^{14} \mathrm{CO}_{2}$ fixation was observed (typically $>5000$ d.p.m. after 30 min incubation with $0.5 \mu \mathrm{g}$ enzyme). Omission of ATP, magnesium or manganese ions, pyruvate or acetyl-CoA from the assay mixture resulted in negligible $\mathrm{CO}_{2}$ fixation ( $<500$ d.p.m. after $30 \mathrm{~min}$ ). The same result was obtained when pyruvate was substituted by a range of other organic acids (2-oxoglutarate, oxalate, L-malate, acetoacetate).

Table 2. Purification of $R$. capsulatus PC by dye-ligand affinity chromatography

\begin{tabular}{|lccccc|}
\hline Step & $\begin{array}{c}\text { Protein } \\
\text { (mg) }\end{array}$ & $\begin{array}{c}\text { Activity } \\
\text { (U) }\end{array}$ & $\begin{array}{c}\text { Specific activity } \\
\left.[\mathbf{U} \text { (mg protein) })^{-1}\right]\end{array}$ & $\begin{array}{c}\text { Purification } \\
(- \text {-fold) }\end{array}$ & $\begin{array}{c}\text { Yield } \\
\text { (\%) }\end{array}$ \\
\hline ICM-free crude extract & 200 & 80 & $0 \cdot 4$ & $1 \cdot 0$ & 100 \\
$40-50 \%\left(\mathrm{NH}_{4}\right)_{2} \mathrm{SO}_{4}$ & 80 & 70 & $0 \cdot 9$ & $2 \cdot 5$ & 87 \\
Blue $\mathrm{MX}-3 \mathrm{~B}$ & $1 \cdot 5$ & 60 & $40 \cdot 0$ & $100 \cdot 0$ & 75 \\
\hline
\end{tabular}


(a)

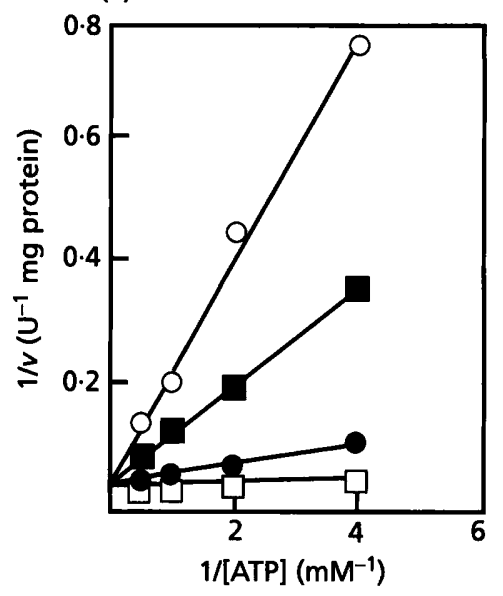

(b)

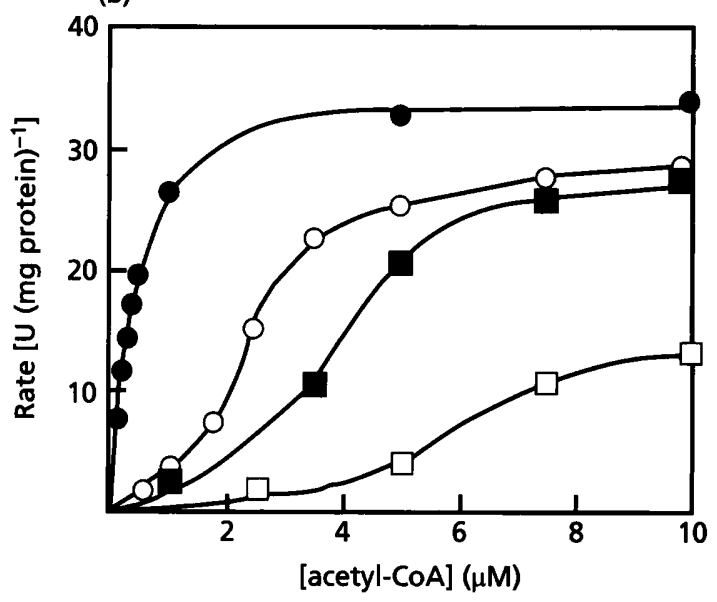

Fig. 5. (a) Competitive inhibition of PC activity by ADP. The initial rate was measured in the absence of ADP ( $\square)$, or in the presence of $0.5 \mathrm{mM} \mathrm{ADP}(0), 1.0 \mathrm{mM}$ ADP ( $)$ or $2.0 \mathrm{mM}$ ADP (O) at various concentrations of ATP. (b) Dependence of PC activity on acetyl-CoA concentration and the effect of inhibitors. The initial rates were measured in the $\mathrm{MDH}$-linked assay in the absence of inhibitors (O) or in the presence of $5 \mathrm{mM}$ L-aspartate (O), $1 \mathrm{mM}$ 2-oxoglutarate $(\square)$ or $5 \mathrm{mM}$ 2-oxoglutarate ( $\square)$.

\section{Inhibition by avidin, ADP, L-aspartate and 2-oxoglutarate}

As is typical of biotin-dependent enzymes, incubation of PC with $1 \mathrm{U}$ avidin almost completely inhibited activity, but inhibition could be prevented completely by preincubation of the enzyme with $0.5 \mu \mathrm{M}$ biotin. ADP was found to be a potent inhibitor of the enzyme, and acted competitively against ATP, as judged by the characteristic double reciprocal plot obtained (Fig. 5a). Of other potential regulatory metabolites tested, L-aspartate and 2-oxoglutarate inhibited the enzyme by antagonizing the activation by acetyl-CoA (Fig. 5b). Kinetic plots of the dependence of rate upon acetyl-CoA concentration in the presence of these inhibitors were markedly sigmoidal (Fig. 5b).
Table 4. Amino acid composition of the $R$. capsulatus PC

\begin{tabular}{|lcc|}
\hline $\begin{array}{l}\text { Amino } \\
\text { acid }\end{array}$ & $\begin{array}{c}\text { No. of } \\
\text { residues }\end{array}$ & mol\% \\
\hline Asx & 119 & $10 \cdot 1$ \\
Glx & 132 & $11 \cdot 2$ \\
Ser & 48 & $4 \cdot 0$ \\
Gly & 123 & $10 \cdot 4$ \\
His & 68 & $5 \cdot 7$ \\
Arg & 93 & $7 \cdot 9$ \\
Thr & 69 & $5 \cdot 8$ \\
Ala & 134 & $11 \cdot 4$ \\
Pro & 62 & $5 \cdot 2$ \\
Tyr & 36 & $3 \cdot 0$ \\
Val & 59 & $5 \cdot 0$ \\
Met & 25 & $2 \cdot 1$ \\
Cys & 10 & $0 \cdot 85$ \\
Ile & 40 & $3 \cdot 4$ \\
Leu & 86 & $7 \cdot 3$ \\
Phe & 26 & $2 \cdot 2$ \\
Lys & 46 & $4 \cdot 0$ \\
Trp & ND & ND \\
Total & 1176 & $99 \cdot 55$ \\
\hline
\end{tabular}

ND, Not determined.

\section{Thermal stability and effects of substrates and acetyl-CoA on heat inactivation}

The purified PC was found to be inactivated rapidly at temperatures above $0-4{ }^{\circ} \mathrm{C}$. For example, after $1 \mathrm{~h}$ incubation of an aliquot at $20^{\circ} \mathrm{C}$ [initial specific activity $36 \mathrm{U}$ (mg protein $)^{-1}$ ], only $25 \%$ of the initial activity remained, and at $50{ }^{\circ} \mathrm{C}$, enzyme activity became undetectable after $15 \mathrm{~min}$. In an investigation of the ability of various compounds to protect the enzyme against heat inactivation at two different temperatures, it was found that acetyl-CoA alone afforded almost complete protection, while various combinations of substrates and cofactors in the absence of acetyl-CoA were ineffective.

\section{Amino-acid composition and $\mathbf{N}$-terminal sequence}

The amino-acid composition of the purified enzyme is shown in Table 4. The compositional relatedness of the $R$. capsulatus enzyme to a range of other PCs was evaluated in terms of the $S \Delta Q$ value, a difference value calculated from a comparison of the amino acid composition of two proteins as defined by Marchelonis \& Weltman (1971), where $S \triangle Q$ values of $<100$ are indicative of compositional relatedness. The results were as follows: chicken liver PC (Scrutton \& Utter, 1965), $S \Delta Q=99$; pig liver PC (Warren \& Tipton, 1974a), $S \triangle Q=88$; yeast PC (product of the $p y c 1$ gene; Lim et al., 1988), $S \Delta Q=61$; Pseudomonas citronellolis (Wallace \& Easterbrook-Smith, $1985), S \Delta Q=318$. Thus, this comparison revealed that only the yeast $\mathrm{PC}$ was significantly compositionally related to the Rhodobacter PC. 


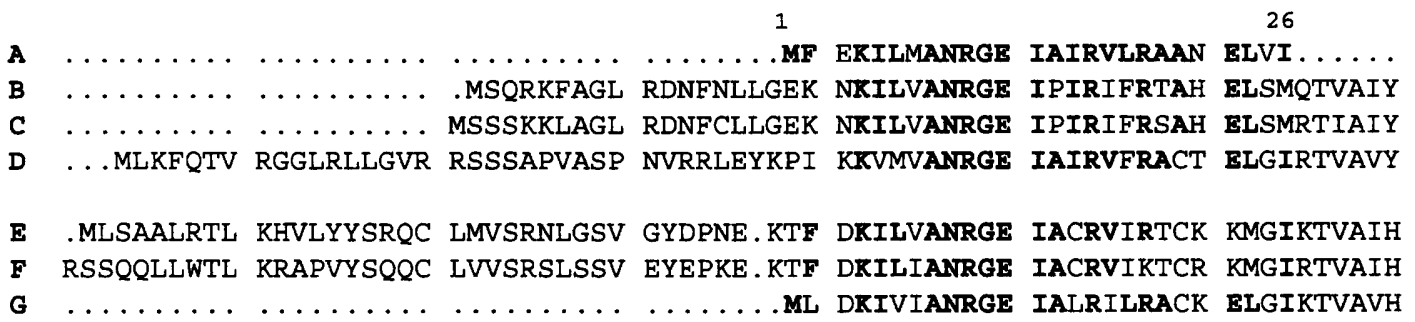

Fig. 6. Multiple sequence alignment of the $\mathrm{N}$-terminal regions of various biotin carboxylases. The sequences compared (with SwissProt accession numbers in parentheses) are: A, R. capsulatus PC (this study); B, yeast PC 1 (P11154); C, yeast PC 2 (P32327); D, mouse PC (Q05920); E, human propionyl-CoA carboxylase, alpha chain (P05165); $F$, rat propionyl-CoA carboxylase, alpha chain (P14882); G, E. coli acetyl-CoA carboxylase, biotin carboxylase subunit (P24182). The alignment was generated using the UWGCG PILEUP program (Devereux et al., 1984) after a SwissProt database search was carried out (using the FASTA program) with the $R$. capsulatus sequence. Residues identical to those in the $R$. capsulatus sequence are in bold.

A sample of the pure enzyme was subjected to the automated Edman degradation procedure and the identity of 26 residues at the $\mathrm{N}$ terminus was determined (Fig. 6). A protein database search revealed significant sequence similarity with the $\mathrm{N}$-terminal regions of several biotindependent carboxylases (Fig. 6), particularly the two yeast PCs (58\% identity) and propionyl-CoA carboxylases from several sources.

\section{DISCUSSION}

In this study, we have developed a simple purification procedure for the acetyl-CoA-dependent PC from the photosynthetic bacterium Rbodobacter capsulatus. A comparison of the standard avidin-affinity method with the dye-linked technique for the $R$. capsulatus enzyme clearly shows the advantages of the latter in terms of both yield and higher final specific activity. The key feature is the highly specific elution of PC activity from the dye column with a relatively low concentration of acetyl-CoA $(50 \mu \mathrm{M})$. However, in view of the determined $K_{\mathrm{a}}$ value of $0.33 \mu \mathrm{M}$, it may be possible to use a considerably lower concentration of acetyl-CoA for elution. The procedure should also be applicable to any other PC which is activated by acetyl-CoA to a significant extent, but we have not determined the exact molecular basis for the success of this method. Indeed, apart from some dehydrogenases, there is general uncertainty as to the mechanism by which many enzymes interact with dye columns (Scopes, 1986). Nevertheless, the absolute dependence and high affinity of the R. capsulatus PC for acetyl-CoA may be an important factor in the specificity of the elution.

The $R$. capsulatus enzyme is clearly a member of the homotetrameric class of $\mathrm{PC}$ which have subunit molecular masses in the region of 110-140 kDa (Scrutton \& Young, 1972). In terms of its absolute requirement for acetyl-CoA and its inhibition by L-aspartate, this enzyme is similar to the B. stearothermophilus PC (Cazzulo et al., 1970), but with the important exception of an extremely low $K_{\mathrm{a}}$ value for acetyl-CoA. A common observation with this class of PCs is an apparent deviation from normal Michaelis-
Menten kinetics with pyruvate as the varied substrate in assays which measure the formation of oxaloacetate (Cazzulo et al., 1970; Scrutton \& Taylor, 1974; Warren \& Tipton, 1974b; Milard de Forchetti \& Cazzulo, 1976). The $R$. capsulatus enzyme also fitted this pattern, giving two linear intersecting lines on double-reciprocal plots from which two apparent $K_{\mathrm{m}}$ values could be extrapolated. This behaviour is due to premature dissociation of pyruvate from the enzyme at low pyruvate concentrations, leading to a hydrolytic breakdown of carboxybiotin and thus an altered reaction stoichiometry (EasterbrookSmith et al., 1976). As demonstrated previously for PC from yeast (Cazzulo \& Stoppani, 1969a), B. stearothermophilus (Cazzulo et al., 1970), Verticillium abo-atrum (Hartman \& Keen, 1974) and Pseudomonas fluorescens (Milard de Forchetti \& Cazzulo, 1976) the optimum pH value for enzymic activity was found to depend upon the nature of the divalent cation present, being at $\mathrm{pH} 7 \cdot 0$ with $\mathrm{MnCl}_{2}$ and $\mathrm{pH} 8.5$ with $\mathrm{MgCl}_{2}$, at equimolar concentrations of ATP and divalent cation. With excess $\mathrm{MgCl}_{2}$, however, the specific activities at each $\mathrm{pH}$ value were higher, and the optimum was shifted to $\mathrm{pH} 8 \cdot 0$. This may be attributed to a separate activation of the enzyme by free $\mathrm{Mg}^{2+}$ (Keech \& Barritt, 1967; Cazzulo et al., 1970; Warren \& Tipton, 1974b). Excess divalent metal cation may also act by converting residual free $\mathrm{ATP}^{4-}$, which has been demonstrated as an inhibitor of some of these enzymes, into the complex ion $\mathrm{MgATP}^{2-}$, the true substrate of the reaction (Cazzulo \& Stoppani, 1969a). The $\mathrm{NaH}^{14} \mathrm{CO}_{3}$ fixation experiment clearly revealed the high specificity of the enzyme for pyruvate as the substrate for $\mathrm{CO}_{2}$ fixation, as other carboxylic, keto- or hydroxyacids tested were ineffective.

Kinetic studies also revealed that ADP competitively inhibited PC activity. Inhibitory effects of ADP have been reported for PCs from fungi (Stan \& Schormuller, 1968), yeast (Cazzulo \& Stoppani, 1969b), B. stearothermopbilus (Cazzulo et al., 1970) and Pseudomonas fuorescens (Milard de Forchetti \& Cazzulo, 1976). L-Aspartate is a potent inhibitor of some PCs of bacterial and fungal origin (Cazzulo \& Stoppani, 1968; Cazzulo et al., 1970; Feir \& Suzuki, 1969; Scrutton \& Young, 1972) but has no effect 
on the enzymes from rat liver, chicken liver (Scrutton et al., 1969), Azotobacter vinelandii (Scrutton \& Taylor, 1974) or Pseudomonas citronellolis (Suebert \& Weicker, 1969). With PC from Aspergillus niger, which is fully active in the absence of acetyl-CoA, L-aspartate is a non-competitive inhibitor with respect to the enzyme substrates (Feir \& Suzuki, 1969). On the other hand, for those microbial enzymes which are activated by acetyl-CoA in an allosteric fashion, inhibition by L-aspartate is co-operative (Cazzulo et al., 1970). This was the pattern found here for the $R$. capsulatus $\mathrm{PC}$, although 2-oxoglutarate was a more potent inhibitor than $\mathrm{L}$-aspartate. The regulation of $\mathrm{PC}$ by acetyl$\mathrm{CoA}$, aspartate and 2-oxoglutarate may have a physiological role in maintaining a balance between catabolic and anaplerotic reactions, analogous to the type of control exerted by acetyl-CoA and aspartate on phosphoenolpyruvate carboxylase in the enterobacteriaceae (where phosphoenolpyruvate rather than pyruvate is the substrate for $\mathrm{CO}_{2}$ fixation; Utter \& Kolenbrander, 1972).

The amino acid composition of only a few PCs (mostly eukaryotic) has been reported in the literature, and thus it was not possible to make detailed estimates of compositional relatedness. $S \triangle Q$ values, calculated from published amino acid compositions, showed the enzyme from $R$. capsulatus to be more related to the acetyl-CoA-stimulated PCs from eukaryotic sources $(S \Delta Q$ values $<100)$ than to the acetyl-CoA-independent PC from $P$. citronellolis $(S \Delta Q=318)$. Unfortunately, no amino acid compositions or even partial sequence data appear to be available for any other bacterial PC. The similarity of the R. capsulatus $\mathrm{PC}$ to the yeast PC was confirmed by comparisons of the $\mathrm{N}$-terminal sequence. The very high degree of sequence identity observed in the $\mathrm{N}$-terminal region strongly suggests that the prokaryotic and eukaryotic PCs in the acetyl-CoA-stimulated class are highly conserved. Elucidation of the evolutionary relationships between these enzymes and the larger family of biotin carboxylases urgently requires more primary sequence information, especially from prokaryotes. The structural gene for the R. capsulatus PC may be contained on PPYC101 and the sequencing of this gene may be important in contributing to such insights.

\section{ACKNOWLEDGEMENTS}

H.V.M. was the recipient of an Overseas Research Student Award from the Committee of Vice-Chancellors and Principals and also acknowledges the British Council and the University of Sheffield for financial support. We thank Dr Paulette Vignais for the gene bank and Dr A. J. G. Moir for performing the aminoacid and $\mathrm{N}$-terminal sequence analysis.

\section{REFERENCES}

Ashman, L. K., Keech, D. B., Wallace, J. C. \& Nielsen, J. (1972). Sheep kidney pyruvate carboxylase. J Biol Chem 247, 5818-5824.

Barden, R. E., Taylor, B. L., Ishohashi, F., Frey, W. H., Zander, G., Lee, J. C. \& Utter, M. F. (1975). Structural properties of pyruvate carboxylases from chicken liver and other sources. Proc Natl Acad Sci 72, 4308-4312.
Buckley, J. J., Libor, S. \& Sundaram, T. K. (1969). Biotin subunits of acetyl CoA carboxylase and pyruvate carboxylase from a thermophilic Bacillus. Arch Biochem Biopbys 192, 396-402.

Cazzulo, J. J. \& Stoppani, A. O. M. (1968). The regulation of yeast pyruvate carboxylase by acetyl-CoA and L-aspartate. Arch Biochem Biophys 127, 563-570.

Cazzulo, J. J. \& Stoppani, A. O. M. (1969a). Effects of magnesium, manganese and adenosine triphosphate ions on pyruvate carboxylase from bakers yeast. Biochem J 112, 747-754.

Cazzulo, J. J. \& Stoppani, A. O. M. (1969b). Effects of adenosine phosphates and nicotinamide nucleotides on pyruvate carboxylase from bakers yeast. Biochem $J$ 112, 755-762.

Cazzulo, J. J., Sundaram, T. K. \& Kornberg, H. L. (1970). Properties and regulation of pyruvate carboxylase from Bacillus stearothermophilus. Proc R Soc Lond B176, 1-19.

Colbeau, A., Godfroy, A. \& Vignais, P. M. (1986). Cloning of DNA fragments carrying hydrogenase genes of $\mathrm{R}$ hodobacter capsulatus. Biochemie 68, 147-155.

Devereux, J., Haeberli, P. \& Smithies, O. (1984). A comprehensive set of sequence analysis programs for the VAX. Nucleic Acids Res $12,387-395$.

Dixon, G. H. \& Kornberg, H. L. (1959). Assay methods for key enzymes of the glyoxylate cycle. Biochem $J$ 72, 3P.

Easterbrook-Smith, S. B., Hudson, P. J., Goss, N. H., Keech, D. B. \& Wallace, J. C. (1976). Pyruvate carboxylase: mechanism of the second partial reaction. Arch Biochem Biopbys 176, 709-716.

Feir, H. A. \& Suzuki, I. (1969). Pyruvate carboxylase of Aspergillus niger: kinetic study of a biotin containing carboxylase. Can J Biochem 47, 697-710.

Fox, D. K. \& Roseman, S. (1986). Isolation and characterisation of homogeneous acetate kinase from Escherichia coli and Salmonella typhimurium. J Biol Chem 261, 3487-3497.

Guest, J. R. \& Creaghan, I. T. (1973). Gene-protein relationships of the $\alpha$-keto acid dehydrogenase complexes of Escherichia coli $\mathrm{K} 12$ : isolation and characterization of lipoamide dehydrogenase mutants. $J$ Gen Microbiol 75, 197-210.

Hamblin, M. J., Shaw, J. G., Curson, J. P. \& Kelly, D. J. (1990). Mutagenesis, cloning and complementation analysis of C4-dicarboxylate transport genes from Rhodobacter capsulatus. Mol Microbiol 4, 1567-1574.

Hanahan, D. (1985). Techniques for transformation of E. coli. In DN A Cloning, a Practical Approach, vol. 1, pp. 109-135. Edited by D. Glover. Oxford: IRL Press.

Hartman, R. E. \& Keen, N. T. (1974). The pyruvate carboxylase of Verticillium abo-atrum. J Gen Microbiol 81, 15-19.

Henrikson, K. P., Allen, S. H. G. \& Malloy, W. L. (1979). An avidin monomer affinity column for the purification of biotin containing enzymes. Anal Biocbem 94, 366-370.

Hess, B. \& Wieker, H. J. (1974). Pyruvate kinase from yeast. In Methods of Enzymatic Analysis, vol. 2, pp. 778-783. Edited by H. U. Bergmeyer. New York: Academic Press.

Hillmer, P. \& Gest, H. (1977). $\mathrm{H}_{2}$ metabolism in the photosynthetic bacterium Rhodobacter capsulatus: $\mathrm{H}_{2}$ production by growing cultures. J Bacteriol 129, 724-731.

Keech, D. B. \& Barrit, G. J. (1967). Allosteric activation of sheep kidney pyruvate carboxylase by the magnesium ion $\left(\mathrm{Mg}^{2+}\right)$ and the magnesium adenosine triphosphate ion $\left(\mathrm{MgATP}^{2-}\right)$. J Biol Chem 242, 1983-1987.

Keech, D. B. \& Wallace, J. C. (1985). Pyruvate carboxylase. CRC Series in Enzyme Biology. Boca Raton, Florida: CRC Press. 
Keen, N. T., Tamaki, S., Kobayashi, D. \& Trollinger, D. (1988). Improved broad host range plasmids for DNA cloning in Gramnegative bacteria. Gene 70, 191-197.

Leyland, M. L. \& Kelly, D. J. (1991). Purification and characterisation of a monomeric isocitrate dehydrogenase with dual coenzyme specificity from the photosynthetic bacterium $R$ hodomicrobium vannielii. Eur J Biochem 202, 85-93.

Lim, F., Morris, C. P., Occhiodoro, F. \& Wallace, J. C. (1988). Sequence and domain structure of yeast pyruvate carboxylase. $J$ Biol Cbem 263, 11493-11497.

Marchelonis, J. J. \& Weltman, J. K. (1971). Relatedness among proteins: a new method estimation and its application to immunoglobulins. Comp Biocbem Pbysiol 38B, 609-625.

Milard de Forchetti, S. R. \& Cazzulo, J. J. (1976). Some properties of the pyruvate carboxylase from Pseudomonas fluorescens. $J$ Gen Microbiol 93, 75-81.

Payne, J. \& Morris, J. G. (1969). Pyruvate carboxylase in Rhodopseudomonas sphaeroides. J Gen Microbiol 59, 97-101.

Phillips, N. F. B., Snoswell, M. A., Chapman-Smith, A., Keech, B. \& Wallace, J. C. (1992). Isolation of a carboxyphosphate intermediate and the locus of acetyl-CoA action in the pyruvate carboxylase reaction. Biochemistry 31, 9445-9450.

Ruiz-Amil, M., de Torrontegui, E., Catalina, L. \& Losada, M. (1965). Properties and function of yeast pyruvate carboxylase. $J$ Biol Chem 240, 3485-3492.

Sambrook, J., Fritsch, E. F. \& Maniatis, T. (1989). Molecular Cloning: a Laboratory Manual, 2nd edn. Cold Spring Harbor, NY: Cold Spring Harbor Laboratory.

Schobert, P. \& Bowien, B. (1984). Unusual C3 and C4 metabolism in the chemoautotroph Alcaligenes eutrophus. J Bacteriol 159, 161-172.

Scopes, R. K. (1986). Strategies for enzyme isolation using dyeligand and related adsorbents. J Cbromatogr 376, 131-140.

Scrutton, M. C. \& Taylor, B. L. (1974). Isolation and characterisation of pyruvate carboxylase from Azotobacter vinelandii. Arch Biochem Biophys 164, 641-684.

Scrutton, M. C. \& Utter, M. F. (1965). Pyruvate carboxylase III. Some physical and chemical properties of the highly purified enzyme. J Biol Cbem 240, 1-9.

Scrutton, M. C. \& Young, M. R. (1972). Pyruvate carboxylase. In The Enzymes, 3rd edn, vol. 6, pp. 1-35. Edited by P. D. Boyer. New York: Academic Press.
Scrutton, M. C., Olmsted, M. R. \& Utter, M. F. (1969). Pyruvate carboxylase from chicken liver. Methods Enzymol 13, 235-248.

Simon, R., Priefer, V. \& Puhler, A. (1983). A broad host range mobilisation system for in vivo genetic engineering: transposon mutagenesis in Gram-negative bacteria. Bio/technology 1, 784-791.

Stan, H. J. \& Schormuller, J. (1968). Regulation of pyruvate carboxylase of Penicillium camemberti by the adenylate system. Biochem Biophys Res Commun 32, 289-294.

Suebert, W. \& Weicker, H. (1969). Pyruvate carboxylase from Pseudomonas. Methods Enzymol 13, 258-262.

Taylor, B. L., Barden, R. E. \& Scrutton, M. C. (1972). Identification of the reacting form of pyruvate carboxylase. J Biol Chem 247, 7383-7390.

Taylor, D. P., Cohen, S. N., Clark, W. G. \& Marrs, B. L. (1983). Alignment of the genetic and restriction maps of the photosynthesis regions of the Rhodopseudomonas capsulata chromosome by a conjugation-mediated marker rescue technique. J Bacteriol 154, 580-590.

Utter, M. F. \& Kolenbrander, H. M. (1972). Formation of oxaloacetate by $\mathrm{CO}_{2}$ fixation on phosphoenolpyruvate. In The Enzymes, 3rd edn, vol. 6, pp. 117-168. Edited by P. D. Boyer. New York: Academic Press.

Wallace, J. C. \& Easterbrook-Smith, S. B. (1985). The structure of pyruvate carboxylase. In Pyruvate carboxylase, pp. 65-108. Edited by B. D. Keech \& J. C. Wallace. Boca Raton, Florida: CRC Press.

Warren, G. B. \& Tipton, K. F. (1974a). Pig liver pyruvate carboxylase. Purification, properties and cation specificity. Biochem $J$ 139, 299-310.

Warren, G. B. \& Tipton, K. F. (1974b). Pig liver pyruvate carboxylase. The reaction pathway for the carboxylation of pyruvate. Biochem J 139, 311-320.

Weaver, P. F., Wall, J. D. \& Gest, H. (1975). Characterisation of Rhodopseudomonas capsulata. Arch Microbiol 105, 207-216.

Willison, J. C. (1988). Pyruvate and acetate metabolism in the photosynthetic bacterium Rhodobacter capsulatus. J Gen Microbiol 34, 2429-2439.

Wooford, N. Q., Beaty, R. S. \& Mclnerney, M. J. (1986). Preparation of cell-free extracts and the enzymes involved in fatty-acid metabolism of Syntrophomonas wolfei. J Bacteriol 167, 179-185.

Received 31 March 1995; revised 12 May 1995; accepted 30 May 1995. 